\title{
People's Unawareness of the Importance of Marriage Certificate
}

\author{
Jamilah $^{1}$, Mega T. Puspita ${ }^{2}$, Endang Dimyati ${ }^{3}$ Tetep $^{4}$, Prima Melati ${ }^{5}$ \\ \{jamilah@institutpendidikan.ac.id ${ }^{1}$, megatiara1515@gmail.com ${ }^{2}$, \\ endangdimyati@institutpendidikan.ac.id ${ }^{3}$ \} \\ Institut Pendidikan Indonesia, Jl. Terusan Pahlawan No.83, Garut 44151 1,2,3,4,5
}

\begin{abstract}
This descriptive study aimed at (1) examining people's possession of marriage certificate, (2) figuring out factors preventing ones from acquiring a marriage certificate, and (3) investigating the efforts of the civil registry office to raise people's awareness of the importance of having marriage certificate. Data were collected through observation, interviews, and documentation. The results of this study revealed that most people did not have marriage certificates. This was due to their unawareness of the importance of marriage certificate, low educational background, and low economic background; hence, they rather had an unregistered marriage. In line with the effort to raise people's awareness of marriage certificate, the civil registry office had reduced the cost of making marriage certificates provided that they could show a relief letter (SKTM) issued by their village administration. The civil registry office also organized a marriage preparation course (SUSCATIN) and socialized the procedures to acquire the marriage certificate.
\end{abstract}

Keywords: people's unawareness, marriage certificate.

\section{Introduction}

Human needs as social beings who cannot live alone lead the humans to form a population called society. One characteristic of social life is that there is interaction in the society. Social interaction becomes the main factor in the relationship between two or more people who influence each other [1]. One of the bonds that exist in human relationship among society is marriage. In the Republic of Indonesia Law Number 1 of 1974 concerning Marriage, Article 1 states that, marriage is physical and conjugal bonds between a man and a woman as husband and wife with the aim of forming a happy, eternal family or household based on the Supreme Divine values. However, there is an issue regarding the low number of people who have marriage certificate, especially in remote areas.

In keeping with the issue of low number of marriage certificate ownership, the previous study concerning people's awareness of having marriage certificate in Karang Tengah Village Community, Cibadak District, Sukabumi Regency, revealed the reasons behind the phenomenon were such as follows [2]:

1. The lack of knowledge and understanding of the importance of ownership of a marriage certificate is one of the community factors neglecting the marriage certificate. For instance, some couples were officially married before a marriage registrar officer/subdistrict religious affairs office; however, the marriage certificate was never taken due to the unawareness of the importance of marriage certificate ownership. 
2. There were some couples who got unregistered marriages. In addition, there was possibility that the marriage guardians in these unregistered marriages did not meet the requirements.

3. Cost issue was another factor mentioned by some couples regarding the reason of not having marriage certificate. Some couples admitted that certain marriage registrar officer doubled costs of making marriage certificates or made the process take too long time. This made the couples especially widows who considered the marriage certificate was not important were reluctant to proceed the marriage certificate ownership.

In general, the findings of previous study above can become the representation for other regions in Indonesia. However, in the district where the site of the present study took place, it was found out that the people were reluctant to deal with the process of making marriage certificate unless there was inspection from the officers or they required the marriage certificate for making a family registration certificate in case of applying for a job. Although the people insisted that they had already married, the married was not registered in the civil registry office. The unregistered marriage causes the husband, the wife, and children born receive no legal protection [3]. Therefore efforts to foster and increase people's awareness especially in the possession of marriage certificates as evidence of one's status whether legitimate or not before the law, may be conducted through the holding of legal counseling as an effort for the law-conscious community.

\section{Objectives of the Study}

There are three main objectives of the present study: to examine people's possession of marriage certificate, to figure out factors preventing ones from acquiring a marriage certificate, and to investigate the efforts of the civil registry office to raise people's awareness of the importance of having marriage certificate.

\section{Method}

The study was a kind of analytical descriptive study which described the phenomenon or occurrences happened during research. Descriptive qualitative method was chosen since this method was able to provide detailed descriptions concerning the background, nature and characteristics of social phenomenon.

\subsection{Technique of Data Collection}

To collect the data of people's awareness of marriage certificate ownership, this study used the techniques of data collection such as follows:

3.1.1 Observation

Observation is a research technique, often called patterns by using observations, which is covered by the activity of focusing attention on an object by using sense devices. Hence, observation of data is conducted through vision, kissing, hearing and through tasting [4]. In collecting the data, the researchers directly observed the objects under study, in the Office of Religious Affairs and in one village in Indonesia. This observation was carried out to find out 
how to increase public awareness of having a marriage certificate in one rural area in Indonesia.

\subsubsection{Interview}

Interview is conversation with specific intention. The conversation is conducted by two parties, namely the interviewer who asks the questions and the interviewee who provides the answers to the questions [5]. Interviews were conducted to find out the reasons for many people who did not have marriage certificates, factors that caused the community to neglect the ownership of marriage certificates, and the efforts made by marriage registrar officers to increase public awareness of having marriage certificates.

Meanwhile, the subjects interviewed in this study were people who did not have a marriage certificate, people who had marriage certificates, KUA officer (registrar of marriage certificate), and Islam leader figure.

\subsubsection{Library Research}

The researchers attempted to collect data based on book references that were related to the study. The reference books used were books about awareness and compliance of law, marriage law, marriage certificates, and other sources that supported this research.

3.1.4 Documentation

Documentation is record of past events; documents can be in the form of writing, pictures or one's monumental works (Sugiyono, 2007:82). The documents required in this study were such as potential data of the village of this research site, the data of people who had a marriage certificate from the hamlet or urban village office, as well as data of people who had unregistered marriage obtained from the Islam leader figure in the village.

\subsection{Population and Sample}

The population of this study was residents of Pasanggrahan Lebak Village, Cilawu District, Garut Regency. The researchers took the sample of 30 married people of the Pasanggrahan Lebak Village community consisted of both women and men.

\section{$4 \quad$ Results and Discussion}

The findings of the study revealed that some of people in Pasanggarahan Lebak Village, Cilawu, Garut had been aware of the importance of marriage certificate ownership, but some others did not care and they thought that there were not any benefits from having marriage certificate at all. This condition of people unawareness of the importance of marriage certificate ownership was derived from low awareness of people for having marriage certificate, low educational background, low economic background, and tradition in the community.

The result of interviews and documentation revealed that the reasons why these people did not have marriage certificate were because of the people's indifference and ignorance attitudes, the people's unawareness of the function and the importance of marriage certificate ownership, and the people's unawareness of the risk of not having marriage certificate. Generally, the people in Pasanggrahan Lebak Village did not know that by having no marriage certificate the children would not have birth certificate, the parents did not have proof of legal marriage, the wives would not have inheritance rights from the husband and also the rights to obtain child custody, people could not apply for a job, and the family would not have any family registration certificate. 
Regarding the causative factor which led the people not to register for marriage certificate ownership, the respondents admitted that they were not afford to have a marriage certificate due to the individual of marriage registrar officer who doubled cost the marriage certificate and they were not able to fulfill the administrative requirements. As a result, the people preferred having unregistered marriage to having legal marriage.

Efforts made by the civil registry office to increase public awareness in the possession of marriage certificates were such as by providing relief fees in making marriage certificates by making a certificate of neighborhood, hamlet and urban village, held a SUSCATIN program, held a socialization on procedures of a marriage certificate ownership, starting from a statement from the neighborhood leader, hamlet and a village certificate to making NA (Marriage Certificate Model), and also providing guidance to villages regarding the importance of having a marriage certificate.

\section{Conclusions}

According to the results and discussion above, it could be concluded that most people had lack of knowledge and understanding regarding the advantages, function and purposes of marriage certificate ownership. This led to economic disparity for parents since their rights as married citizens were not recognized by law. In addition, children and wives from unregistered marriages would face obstacles in obtaining inheritance rights. Moreover, in an unregistered marriage family, the children would only receive birth certificate with only mother's name listed on it.

The importance of having marriage certificate could be seen in the case of children tuition fee assistance. Children from unregistered marriage were difficult to gain tuition fee assistance. Therefore, the government especially civil registry office required to socialize more the importance of marriage certificate ownership in order to motivate the married people to have marriage certificate.

The researchers assume that if the married people are aware of the importance of having a marriage certificate, the role of government to provide donation will be easier. Other advantages of having marriage certificate are such as education of children is guaranteed, people will be able to obtain loan from the bank, the rights of life of wives, husbands, and children will be guaranteed because all the things that later require proof of the marriage certificate will no longer be a problem and polemic in people's lives. If later acts of violence occur in the household, victims can claim their rights as part of a legitimate community to file a lawsuit because they have a marriage book or marriage certificate, both male and female, and automatically the child will not be neglected. Mothers or fathers who have the right to care for children of divorce must take care of their biological children. If the mothers or fathers do not care for the children, the children can also propose protection to the local child protection or National Commission on Human Rights.

\section{Recommendations}

Derived from the conclusions above, the recommendations for related parties are such as follows: 
1. To prospective brides who are going to get married firstly must prepare themselves economically, mentally and physically. Between the bride and groom must be aware that unregistered marriage will harm the wife and the children since the wife will not have an official status before the law, has no right to inheritance and also the status of the child is not clear.

2. Parents must give full support to their children to be legally married before the law by making marriage certificates and convincing their married children about the importance of having a marriage certificate. Even though the prospective bride's parents did not make a marriage certificate in the past, the parents did not influence their children to follow the parents.

3. The government, especially the local government, is expected to be more active in conducting counseling or outreach to the community, especially people in remote areas so as to minimize the occurrence of underage marriages and to help the community fulfill administrative requirements in making marriage certificates.

4. The duties and functions of the BP4 (Marriage Advisory, Supervision and Preservation Agency) are further enhanced to prevent divorce and advise those who are married so that there is no underage marriage and unregistered marriage.

5. The community is expected to be able to realize the importance of making a marriage certificate and not to cultivate underage marriage and unregistered marriage. Therefore, the people can find out the usefulness of making a marriage certificate for the future.

\section{References}

[1] Fatnar.: Kemampuan Interaksi Sosial. Jurnal Fakultas Psikologi. Vol.2 (2014)

[2] Fatimah, Nunung.: Dalam Suatu Kajian Tentang Peningkatan Kesadaran Masyarakat Untuk Memiliki Akta Perkawinan (Studi Kasus Terhadap Masyarakat Desa Karang Tengah Kecamatan Cibadak Kabupaten Sukabumi). Unpublished paper (2013)

[3] Usman, Rachmadi.: Makna Pencatatan Perkawinan Dalam Peraturan Perundang-undangan Perkawinan di Indonesia. Jurnal Legislasi Indonesia. Vol. 14, No. 3 (2017)

[4] Arikunto, Suharsimi.: Dasar-Dasar Evaluasi Pendidikan. Jakarta: Bumi Aksara (2002)

[5] Lexy J, Moleong.: Metodologi Penelitian Kualitatif. Bandung: Remaja Rosda Karya (2009) 